\title{
DEMOLITION OF ABANDONED BASEMENT IN CONGESTED URBAN AREA
}

\author{
Jiin-Song Tsai $^{(1)}$, Lee-Der Jou ${ }^{(2)}$ and Fu-Chen Liu ${ }^{(3)}$
}

\author{
(1) Professor \\ Department of Civil Engineering \\ National Cheng Kung University \\ Tainan, Taiwan, 70101, R.O.C. \\ (2) (3) Assistant Professor and Lecturer \\ Department of Civil Engineering \\ Nan Jeon College of Technology and Commerce \\ Tainan County, Taiwan, R.O.C.
}

Tel:+886-6-2757575 ext.63123, E-Mail: jstsai@mail.ncku.edu.tw

\begin{abstract}
This paper presents two cases of basement demolition in built-up urban area. Micropiles in conjunction with proper groundwater drawdown using well points are adopted in the first case as temporary retaining during the period of basement demolition and removal. Watertight sheet piles with internal bracing struts are used in the second case to resist earth pressure and groundwater pressure. During the entire course of construction, both cases were successfully executed without disturbing adjacent ground and damaging buildings at a close proximity. This paper emphasizes that a sufficient knowledge on ground behavior and a good sense on construction details are prerequisites for such complicated excavation projects.
\end{abstract}

Keywords: basement demolition, deep excavation, congested urban area, displacement method, replacement method, micropile, sheet pile, diaphragm wall.

\section{INTRODUCTION}

Land is a rare commodity in congested urban area. Urban renewal in the form of redeveloping a piece of land to a higher value is now a regular thought, therefore, demolishing an old building to make room for the construction of a new high-rise building is not uncommon nowadays. The associated deep excavation involving the removal of abandoned basement in a congested metropolitan area has thus become a new challenge for today's foundation engineers.

For deep excavation, it is well known that tight construction space and difficult ground conditions are the two major obstacles for design and field engineers. In a congested urban area, construction space is always tight. In this study, abandoned basement encountered in deep excavation site presents yet another particular kind of difficult ground condition. To make things worse, if the project site is surrounded by old and fragile buildings, minor construction activities may induce tilting or cracks on these buildings. This may trigger large scale damage lawsuit. Once happened, it is definitely a disaster for every party involved in the project.

It is worth noting that certain regulations are now implemented in some major cities, such as Taipei and Kaohsiung, that contractor is responsible for the safety of surrounding buildings within an apparent influence range (Ou et al., 1993). This range is defined as the horizontal distance from the edge of excavation to the location where the excavation induced ground settlement is insignificant. Depending 
on geological conditions, this distance may range from two to five times the excavation depth (Tsai, 1995). Under this circumstance, effective construction method and building protection measures have to be undertaken in order to safeguard the ensuing excavation, otherwise the whole project may be in jeopardy because of lawsuits between project owners and a large group of neighboring residents.

Major researches on deep excavation have been conducted for more than three decades. It appears that there are far too many uncertainties involved, and experience as well as judgement are still required. For the problem of removing an abandoned basement in the construction site, the solution is not in the textbook. Experiences on past cases are generally followed in real world practices. Old wisdom has indicated that case history is a source of knowledge. It is thus of interest to present successful cases for future interests.

\section{GENERAL ASPECTS OF EXCAVATION RELATED PROBLEMS}

In urban area where land is precious, a basement would most likely be built up to the boundary of land, and the associated deep excavation is thus carried out very close to existing buildings. A tight clearance of less than $20 \mathrm{~cm}$ between the excavation and the adjacent buildings is not uncommon. It is obvious that construction quality of the excavation will directly affect the safety of surrounding buildings. Previous studies (Peck, 1943; Caspe, 1966; Terzaghi and Peck, 1967; Peck, 1969; Mana and Clough, 1981; O'Rourke, 1981) have all indicated that the surrounding ground would settle during excavation. Fundamental soil mechanics explains that ground deformation occurs as a result of unbalanced loading of earth/water pressure inside and outside of the excavation. Consolidation theory (Terzaghi and Peck, 1967; Lowe, 1971) reveals that unloading-reloading cycles exerting on soil mass as a result of any kind of construction activities would induce further ground deformation and settlement. Stress and strain path theories (Lambe, 1964; Parry, 1995) indicate that irrecoverable deformation (or settlement) of soil mass of every unloading-reloading cycle will gradually accumulate during the entire course of excavation.

As mentioned above, deep excavation as a soil dislodgement work which an operation highly dependent on the natural of in-situ soil properties and its associated behaviors. In fact, the amount of the excavation induced ground settlement also depends on a lot of factors, such as groundwater condition, excavation geometry, excavation sequence, duration of excavation, surcharge conditions, existence of adjacent buildings, retaining wall construction method, penetration depth and stiffness of retaining wall, type and installation method of lateral supports, spacing and stiffness of struts, strut preload, timing of prestress, and etc. Experiences have shown that no matter how well controlled, excavation will result in ground settlement, which may in turn induce structural or non-structural damage of adjacent buildings. Experiences further show that building damage often occurs in a fairly large scale, neighborhood within a radius of two to four times of the excavation depth can more or less feel the punch (Woo and Moh, 1990). Loosely translated, up to several hundred neighboring residents may file for damage lawsuit or ask for compensation, which is bound to be a major headache for every party involved in the project.

\section{CONSTRUCTION METHODS}

One of the decisions confronting the engineers in planing earthmoving operations is the choice of a proper construction method and procedure. For a particular deep excavation project which requires the removal of old basement before hand, the new retaining wall will likely to encounter the old basement wall. The old basement wall will hinder the construction of new retaining wall. From a practical point of view, it is better to construct the new retaining wall in a least disturbance way. In general, there are two basic methods for constructing the new retaining wall: (1) displacement method and (2) replacement method.

Displacement construction method is to use the old basement wall as guide wall for subsequent retaining wall construction. Schematic diagrams are shown in Fig. 1. The old basement wall is not fully taken off until the new retaining wall is accomplished. On the other hand, if there is no fringe space available because old basement has been built to the boundary of land, new retaining wall has to be built on the location of old basement wall. Figure 2 shows a practice of typical replacement construction method, in which old basement wall is drilled off using a large diameter powered auger and the bored holes are then back-filled with concrete and reinforcements. It is worth noting that displacement method is relatively convenient for contractors equipped only with conventional equipment and technique, while the replacement method may require special construction equipment. The case presented in this paper are applications of displacement method. Details on the demolition and removal of abandoned basement are described.

\section{CASE STUDY}


The first case is located in Kaohsiung, Taiwan. The new building is a 35 -story highrise with a 5-story basement. To build the new basement, an excavation of $22.3 \mathrm{~m}$ in depth is performed, and a $36 \mathrm{~m}$ deep reinforced concrete diaphragm wall is built to resist earth/groundwater pressure. Site plan (Fig. 3) shows that construction site is of $70 \mathrm{~m}$ long by $32 \mathrm{~m}$ wide, and is surrounded by existing buildings along three sides. Only narrow fringe space is available between boundaries of the new building and those existing ones. A river locates at a distance of about $35 \mathrm{~m}$ from west side of the construction site. Field investigation indicates that the groundwater table is at about 3.0 to $3.3 \mathrm{~m}$ below the grade, and is apparently influenced by the water level of the nearby river. Geological investigation indicates that the subsurface consists mainly of interbedded silty sand and silty clay layers to a depth of at least $50 \mathrm{~m}$. These soils are classified as SM or CL according to the Unified Soil Classification System (USCS). Blow count numbers of the standard penetration test range from 10 to 40 , which shows that subsurface mainly consists of medium dense to dense sand and stiff clay layers. It is noted that there is a single story basement abandoned in the site. This basement was built to a depth of $5 \mathrm{~m}$. Locations of the old and the new basements are shown in Fig. 4.

As can be seen in Fig. 4, the diaphragm walls on east and west sides of the new basement can be built following a standard construction procedure. However, diaphragm wall construction on the other two sides needs to consider the difficult ground condition imposed by the existence of abandoned basement. Furthermore, the safety of the adjacent buildings along north boundary has to be ensured. Details on the construction of guide wall for subsequent diaphragm wall construction on both north and south boundaries are described in the following. The procedure outlines in both the preliminary planning stage and the actual field execution stage are all described for a better comparison.

In the preliminary planning stage, works to remove old basement walls and construct new guide walls are planned in stages. For guide wall construction on south boundary, micropiles are adopted in an early stage to retain adjacent ground during the removal of old basement wall.

Stage 1: Slab of the old basement floor is opened to provide space for new guide wall construction. Surface of the foundation slab is chipped off by 20 $\mathrm{cm}$ to install the guide wall's footing. It is noted that the foundation slab is built to a depth of $5 \mathrm{~m}$, and slab of the old basement floor is at $2.8 \mathrm{~m}$ below grade.
Stage 2: New guide wall on the excavation side is constructed. Buttresses are also built to provide lateral support for the guide wall.

Stage 3: A line of micropiles $9 \mathrm{~m}$ in length and 20 $\mathrm{cm}$ in diameter are installed with a $20 \mathrm{~cm}$ spacing. They are constructed along fringe of the old basement, and are at a distance of about $30 \mathrm{~cm}$ from outer face of the proposed diaphragm wall. In addition, well points are installed in another line at 6 $\mathrm{m}$ spacing, and they are located in a distance of 80 $\mathrm{cm}$ away from the micropiles. These well points are installed to a depth of $9 \mathrm{~m}$, and groundwater is then lowered to $5.5 \mathrm{~m}$ below grade. After the auxiliary measures are accomplished, the old basement wall is demolished to $2.5 \mathrm{~m}$ below grade.

Stage 4: Rest of the old basement wall is removed to $5 \mathrm{~m}$ below grade, and new guide wall on the retaining side is built up against the self-standing face of micropiles. To maintain the clearance between guidewalls for subsequent diaphragm wall construction, round wood-logs are inserted as temporary spacers.

The guide walls on the north boundary are also constructed using similar techniques. As shown in Fig. 5, micropiles are installed at an inclination of 0 or 10 degrees. Well points of $9 \mathrm{~m}$ in depth are also installed in order to draw down ground water.

Using the standard procedures described above as a basis, minor modifications are made by engineers supervising the field work. Removal of the old basement wall is modified into two stages in order to have a better support of the micropiles. Another modification is to construct the guide walls on the excavation and retaining sides at the same time in two lifts. Representative execution stages on the south boundary are described in the following.

Stage 1: Micropiles and well points are installed according to stage 3 as delineated in the original plan.

Stage 2: As shown in Fig. 6, part of the old basement wall is removed to a depth of $2.5 \mathrm{~m}$. Inclined struts with hydraulic jacks are installed at column locations of the abandoned basement to provide lateral support for the micropiles (Fig. 7).

Stage 3: After the groundwater has been lowered to GL. $-5.5 \mathrm{~m}$, rest of the old basement wall is demolished. New guide walls on retaining and excavation sides are constructed to their half-height (Fig. 8). Clearance between guide walls is ensured by using wood logs as temporary spacers. Vacancy of the old basement is back-filled to the same height of the half-completed guide walls. 
Stage 4: As shown in Fig. 9, the inclined struts are removed, and the guide walls are constructed up to the ground level. Vacancy of the old basement is back-filled completely.

The new guide walls on the north boundary are constructed following the same procedure as in the original plan. After all guide walls are completed, the abandoned basement is back-filled to ground level. A reinforced concrete pavement is then cast on top of the leveled ground, allowing the heavy diaphragm wall construction equipment to move in. Standard procedure for diaphragm wall construction and deep excavation are then employed.

\section{SUMMARY}

Owing to the scarcity of land resources in metropolitan areas, demolishing old buildings to construct new ones are not uncommon. In this regard, the removal of abandoned basement has become a unique problem for today's deep excavation industry. This paper presents a successful excavation where the old basement must be demolished in advance to make room for the construction of new diaphragm walls. With fragile buildings situated nearby, both cases use innovative schemes to construct guide walls. The presented approaches provide valuable references for future projects with similar problems. These approaches can be summarized as follows.

1. Micropiles can serve as an effective temporary retaining wall. Dewatering may be required if the ground water level is high.

2. Removal of abandoned basement must be executed under proper procedure. Perimeter wall of the abandoned basement can sometimes be used as temporary retaining system.

3. Vacancy left by the removal of old basement has to be back-filled to the ground level in order that subsequent diaphragm wall construction can be proceeded.

\section{ACKNOWLEDGMENTS}

Financial supports from the National Science Council project NSC 87-0209-E006-021 is acknowledged.

\section{REFERENCES}

[1] Caspe, M.S. (1966). "Surface settlement adjacent to braced open cuts." ASCE Journal of the Soil Mechanics and Foundation Engineering Division, ASCE, Vol. 92, July, pp. 51-59.

[2] Lambe, T.W. (1964). "Methods of estimating settlement." ASCE Journal of the Soil Mechanics and Foundation Engineering Division, ASCE, Vol. 90, No. SM5, p. 43.
[3] Lowe, J, (1971). "New concepts in consolidation and settlement analysis." Presented at the American Society of Civil Engineers Annual and National Environmental Engineering Meeting, St. Louis, Missouri, Oct. 21, 1971.

[4] Mana, A.I., and Clough, G.W. (1981). "Prediction of movements for braced cut in clay." ASCE Journal of geotechnical Engineering, ASCE, Vol. 107, June, pp. 759777.

[5] O'Rourke, T.D. (1983). "Ground movements caused by braced excavations.” ASCE Journal of Geotechnical Engineering, ASCE, Vol. 107, September, pp. 1159-1178.

[6] Ou, C.Y., Hsieh, P.G. and Chiou, D.C. (1993). "Characteristics of ground surface settlement during excavation." Canadian Geotechnical journal, Vol. 30, pp. 758-767.

[7] Parry, R.H.G. (1995). Mohr circles, stress paths and Geotechnics. E \& FN Spon, London, U.K.

[8] Peck , R.B. (1943). "Earth-pressure measurements in open cuts, Chicago subway." Trans. ASCE, 108, pp.1008-1036. Record of settlements due to excavation of open cut in soft clay.

[9] Peck , R.B. (1969). "Deep Excavation and tunneling in soft ground." Proceedings of the 7th International Conference on Soil Mechanics and Foundation Engineering, State-of-the-Art Volume, pp.225-290, Mexico City, Mexico.

[10] Terzaghi, K. and Peck, R.B. (1967). Theoretical soil mechanics. John Wiley \& Sons, Inc., New York, N.Y.

[11] Tsai, J.S. (1995). Study of apparent influence range of excavation induced ground settlement for Kaohsiung metropolitan area. A report to Kaohsiung Architect Association (in Chinese).

[12] Woo, S.M. and Moh, Z.C. (1990). "Geotechnical Characteristics of Soils in Taipei Basin." Proceedings, 10th Southeast Asian geotechnical Conference, Vol. 2, pp. 51-65, Taipei, Taiwan. 


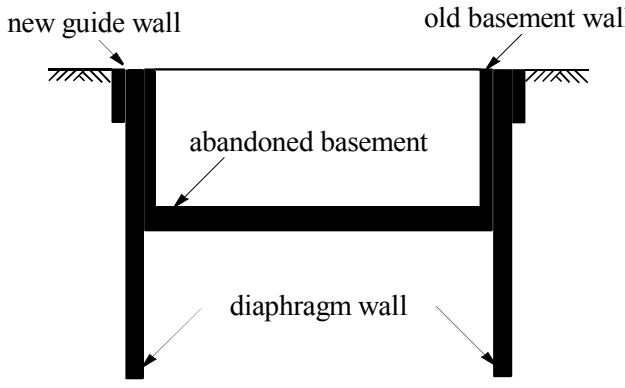

(a) use of abandoned basement wall as inner guide wall for subsequent diaphragm wall construction

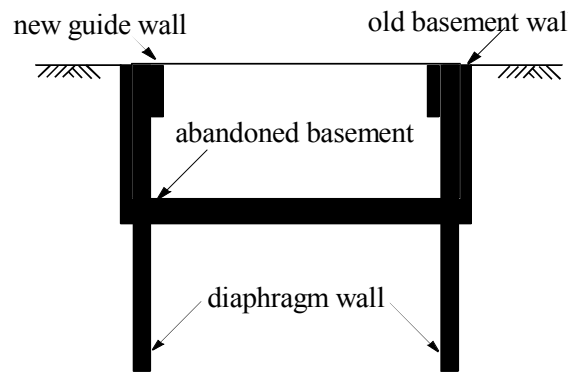

(b) use of abandoned basement wall as outer guide wall for subsequent diaphragm wall construction

Fig. 1 Displacement method for the demolition of abandoned basement

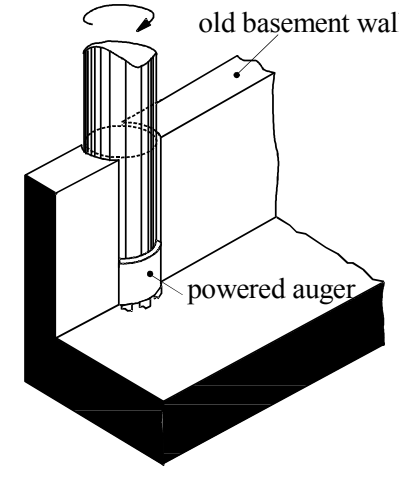

(a) demolition of old basement wall

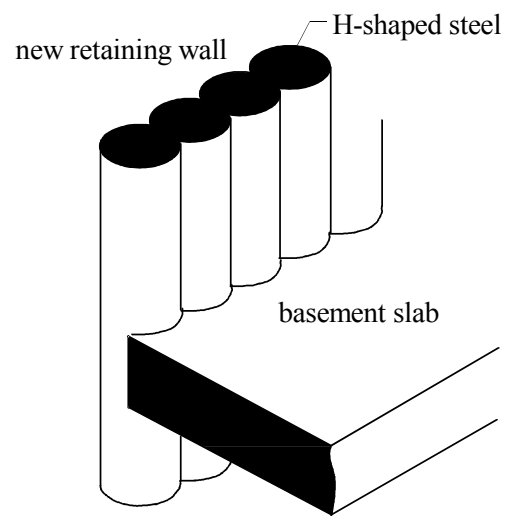

(b) new retaining wall

Fig. 2 Replacement method for the demolition of abandoned basement 


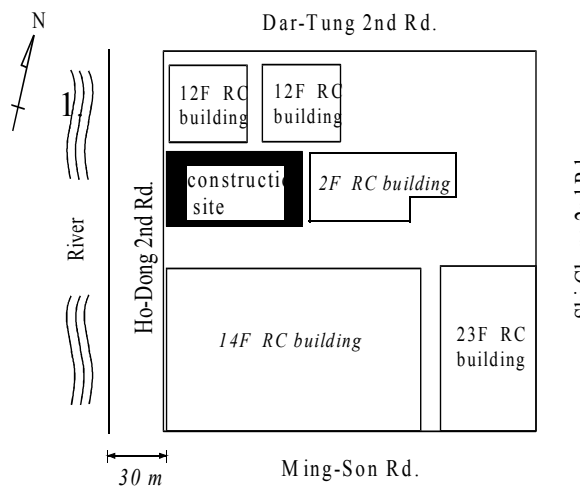

Fig. 3 Site plan of case

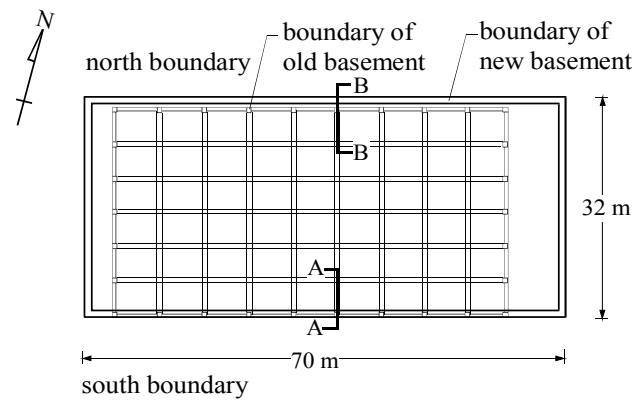

Fig. 4 Location of old and new basements

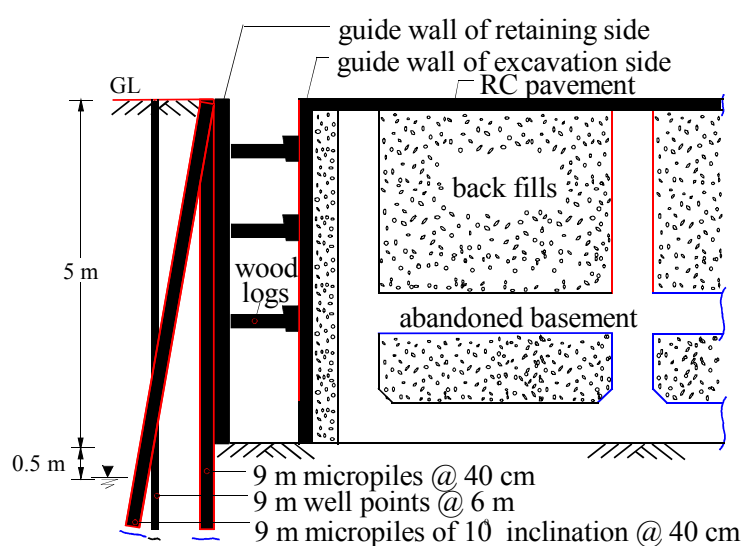

Fig. 5 Guide wall construction on north boundary (planning stage, section B-B of Fig. 4)

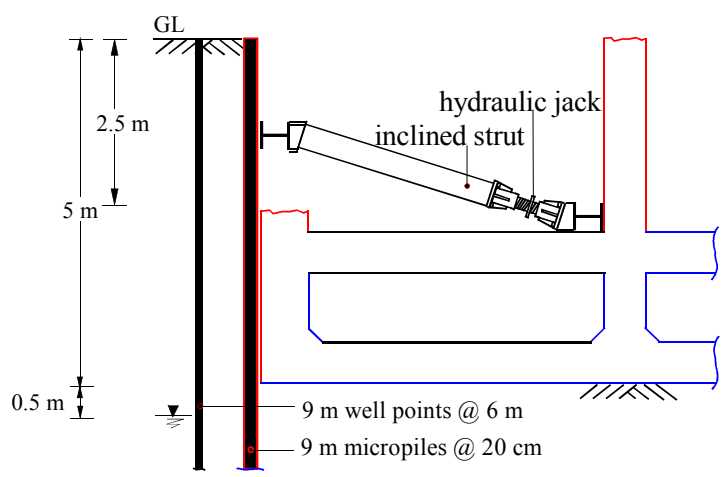

Fig. 6 Stage 2 for old basement wall demolition and new guide wall construction on south boundary (execution stage, section A-A of Fig. 4)

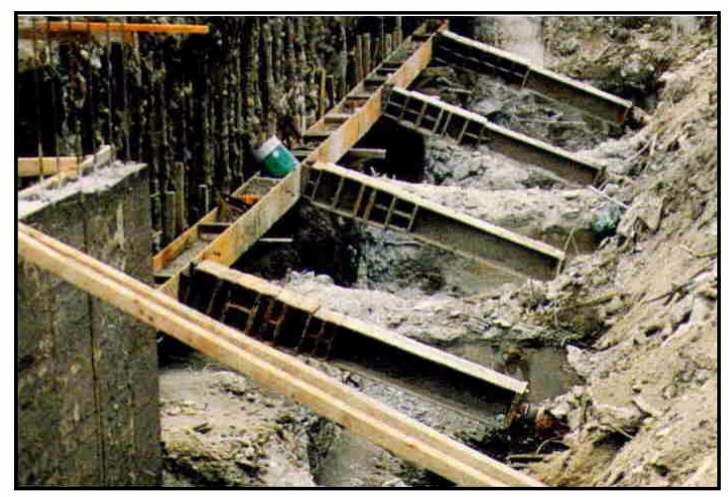

Fig. 7 Inclined struts as lateral support for micropiles

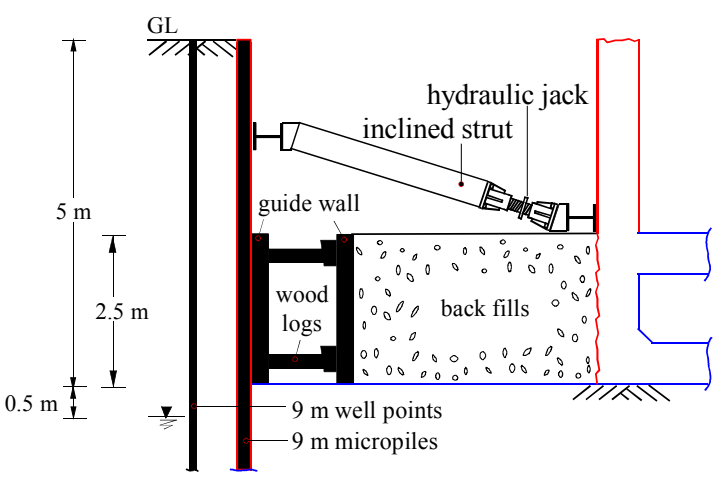

Fig. 8 Stage 3 for old basement wall demolition and new guide wall construction on south boundary (execution stage, section A-A of Fig. 4)

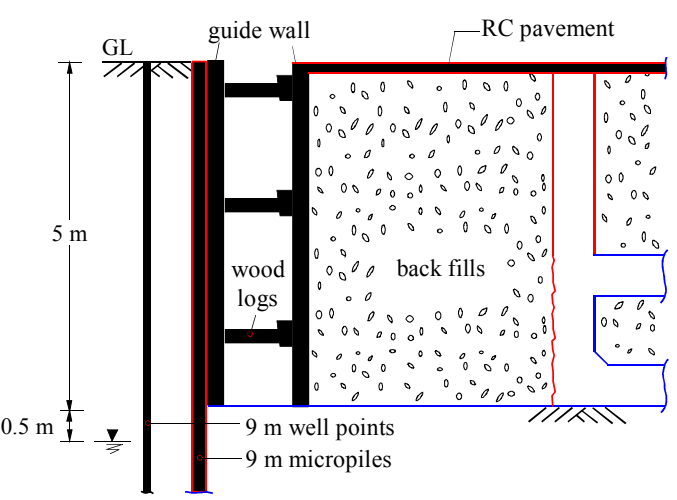

Fig. 9 Stage 4 for old basement wall demolition and new guide wall construction on south boundary (execution stage, section A-A of Fig. 4) 